\title{
Main elements of nutrition content in the soil for maize crops, depending on the predecessors and methods of soil treatment
}

\author{
Alexey Kozhukhov ${ }^{1}$, Alexander Gurin ${ }^{1}$, and Svetlana Rezvyakova ${ }^{1, *}$ \\ ${ }^{1}$ Oryol state agrarian University named after N. V. Parakhin, 302019, Oryol, Russia
}

\begin{abstract}
The article presents data on the study of the main nutrition elements in the soil under maize crops, depending on the predecessors and methods of soil treatment in the conditions of ordinary Chernozem. The object of research is a Krasnodarsky 194MV hybrid of maize. Variants: 1. Fallow arable land (control); 2. Lupine as green manure; 3. Peas as green manure; 4. Binary sowing of lupine and peas as green manure; 5. Soy as green manure. The experiment was repeated three times, field placement was randomized, and area of each was $120 \mathrm{~m}^{2}$. Agrotechnics of maize cultivation in the experiment corresponded to the recommendations for this zone. Green manure was plowed in during its reproduction phase. In the variants with green mass plowing to a depth of $23-25 \mathrm{~cm}$, the largest amount of nitrate nitrogen was in the soil layer $0-20 \mathrm{~cm}$. In the specified soil horizon, before sowing maize, the content of nitrate nitrogen ranged, depending on the variant, from $24.7 \mathrm{mg} / \mathrm{kg}$ to $42.8 \mathrm{mg} / \mathrm{kg}$. In the soil layer 20 $40 \mathrm{~cm}$, the amount of nitrogen was lower, just $19.4-29.5 \mathrm{mg} / \mathrm{kg}$. Similar dependence was observed for maize during its flowering phase. Tillage methods had almost no effect on the accumulation of nitrate nitrogen in the upper soil layer $(0-20 \mathrm{~cm})$. As in all the variants, the differences in this indicator were within the experimental error. However, the content of nitrate nitrogen during the growing season was different. The greatest amount of it was observed during the spring period, both in versions with plowing to a depth of $25-28 \mathrm{~cm}$ and in versions with blade loosening to a depth of $10-12 \mathrm{~cm}$. The smallest amount of available phosphorus, regardless of the method of soil preparation, in the layer $0-20 \mathrm{~cm}$ was on fallow arable land $122 \mathrm{mg} / \mathrm{kg}$ during the sowing period and $104 \mathrm{mg} / \mathrm{kg}$ during the flowering period. In variants with cultivation of legumes as green manure, the content of available phosphorus in the specified horizon was significantly chigher, being $147-171 \mathrm{mg} / \mathrm{kg}$. The highest content of exchangeable potassium was provided by lupine $209-213 \mathrm{mg} / \mathrm{kg}$ in the $0-20 \mathrm{~cm}$ soil layer, and lupine sown together with peas $-196-207 \mathrm{mg} / \mathrm{kg}$. The minimum amount of exchangeable potassium was $143-146 \mathrm{mg} / \mathrm{kg}$ in fallow arable land, depending on the method of soil treatment.
\end{abstract}

\section{Introduction}

Nowadays, it is important not only to obtain high yields of agricultural products, but also to preserve the fertility of soils. Restoring fertility of soils and creating zerodeficit balance of nutritional elements is the most important task of agriculture, solution of which is based on application of organic fertilizers. [1-5].

The most common way to provide soil with organics is to use manure [6-9]. However, in recent years there has been a shortage of cattle manure (CM). In this regard, the use of green manure as organic fertilizer, which in its properties is equivalent to manure, is highly important. When plowing in the green mass of green manure in the amount of 35-40 t/ha, the soil gets up to $150-200 \mathrm{~kg} / \mathrm{ha}$ of nitrogen. It is important that the nitrogen mineralization rate of the crushed mass of plants in the first year after the introduction is twice as high as that of manure [10-12].
The green manure crops with the greatest effect are legumes, including annual legumes such as lupin, vetch, peas, soy, etc. $[1,13,14]$.

Domestic and foreign experience shows that in the current state of agricultural production, green manure should be considered an important link of energy and resource-saving technologies for the production of crops [15-18].

Maize is one of the leading grain and forage crops not only in Russia, but also worldwide [19-21].

Intensification of maize cultivation for silage production requires not only placing it in specialized crop rotations, but also making correct scientific justification for the selection of green manure, ensuring the increased productivity of high-quality silage mass with the lowest costs, while preserving the fertility of the soil [16, 22-24].

The goal of the study is to study the nutrient regime of the soil for growing maize, depending on the type of green manure, on the black-earth soils of the Central Black Earth region (CBER).

\footnotetext{
* Corresponding author: lana8545@yandex.ru
} 


\section{Materials and methods}

The object of the study is a maize hybrid Krasnodarsky $194 M V$.

Options:

1. Fallow arable land (control);

2. Lupine as green manure;

3. Peas as green manure;

4. Binary sowing of lupine and peas as green manure;

5. Soy as green manure.

The experiment was repeated three times, the field placement was randomized, each field's area was 120 $\mathrm{m}^{2}$. Agrotechnics of maize cultivation in the experiment corresponded to the recommendations for the area. Green manure was grinded and mixed into the soil at the reproduction phase. In the control variant, $20 \mathrm{t} / \mathrm{ha}$ of cattle manure was applied.

Nitrate nitrogen content in the soil was determined according to GOST 36107-84, mobile forms of nitrogen and potassium were determined by the Chirikov method in the CRIAS (Central Research Institute of Agricultural Services) (GOST 26204-91) modification.

\section{Results and Discussion}

The results of the study showed that green manure affected the nitrate nitrogen content in the soil for growing maize (table 1).

Table 1. Nitrate nitrogen content of the soil for growing maize, depending on the predecessor and the method of soil preparation, $\mathrm{mg} / \mathrm{kg}(2016-2019)$.

\begin{tabular}{|c|c|c|c|c|}
\hline \multirow{2}{*}{$\begin{array}{c}\text { Predecessors } \\
\text { (Factor A) }\end{array}$} & \multirow{2}{*}{$\begin{array}{c}\text { Soil } \\
\text { treatment } \\
\text { (factor B) }\end{array}$} & \multirow{2}{*}{$\begin{array}{c}\text { Layer } \\
\text { of soil, } \\
\text { cm }\end{array}$} & \multicolumn{2}{|c|}{ Sampling dates } \\
\hline & & & Sowing & Flowering \\
\hline \multirow{2}{*}{$\begin{array}{l}\text { Fallow arable } \\
\text { land (control) }\end{array}$} & \multirow{10}{*}{$\begin{array}{l}\text { Plowing } \\
\text { to the } \\
\text { depth of } \\
25-28 \mathrm{~cm}\end{array}$} & $0-20$ & 24.7 & 17.9 \\
\hline & & $20-40$ & 19.4 & 10.6 \\
\hline \multirow{2}{*}{$\begin{array}{l}\text { Lupine as green } \\
\text { manure }\end{array}$} & & $0-20$ & 42.8 & 29.8 \\
\hline & & $20-40$ & 27.4 & 20.8 \\
\hline \multirow{2}{*}{$\begin{array}{l}\text { Peas as green } \\
\text { manure }\end{array}$} & & $0-20$ & 37.1 & 23.3 \\
\hline & & $20-40$ & 29.5 & 21.9 \\
\hline \multirow{2}{*}{$\begin{array}{l}\text { Lupine and peas } \\
\text { as green manure }\end{array}$} & & $0-20$ & 41.2 & 24.7 \\
\hline & & $20-40$ & 25.1 & 18.5 \\
\hline \multirow{2}{*}{$\begin{array}{l}\text { Soy as green } \\
\text { manure }\end{array}$} & & $0-20$ & 36.2 & 22.3 \\
\hline & & $20-40$ & 24.7 & 19.2 \\
\hline \multirow{2}{*}{$\begin{array}{l}\text { Fallow arable } \\
\text { land (control) }\end{array}$} & \multirow{10}{*}{$\begin{array}{l}\text { Blade } \\
\text { loosening } \\
\text { to the } \\
\text { depth of } \\
10-12 \mathrm{~cm}\end{array}$} & $0-20$ & 21.3 & 17.4 \\
\hline & & $20-40$ & 16.1 & 12.3 \\
\hline \multirow{2}{*}{$\begin{array}{l}\text { Lupine as green } \\
\text { manure }\end{array}$} & & $0-20$ & 40.7 & 23.8 \\
\hline & & $20-40$ & 17.3 & 14.6 \\
\hline \multirow{2}{*}{$\begin{array}{l}\text { Peas as green } \\
\text { manure }\end{array}$} & & $0-20$ & 35.4 & 22.7 \\
\hline & & $20-40$ & 16.1 & 13.2 \\
\hline \multirow{2}{*}{$\begin{array}{l}\text { Lupine and peas } \\
\text { as green manure }\end{array}$} & & $0-20$ & 36.1 & 26.3 \\
\hline & & $20-40$ & 15.2 & 12.8 \\
\hline \multirow{2}{*}{$\begin{array}{l}\text { Soy as green } \\
\text { manure }\end{array}$} & & $0-20$ & 34.6 & 20.9 \\
\hline & & $20-40$ & 16.4 & 11.3 \\
\hline
\end{tabular}

In variants with plowing green mass to a depth of $23-25 \mathrm{~cm}$, the largest amount of nitrate nitrogen was in the soil layer $0-20 \mathrm{~cm}$. In this horizon, the nitrate nitrogen content ranged between $24.7 \mathrm{mg} / \mathrm{kg}$ and $42.8 \mathrm{mg} / \mathrm{kg}$, depending on the predecessor. In the soil layer $20-40 \mathrm{~cm}$ content of nitrogen was less - 19.4-
$29.5 \mathrm{mg} / \mathrm{kg}$. We have observed a similar pattern during the flowering phase of maize. In that phase, content of nitrogen was significantly less. In the layer $0-20 \mathrm{~cm}$ it was $17.9-29.1 \mathrm{mg} / \mathrm{kg}$ and in the layer $20-40 \mathrm{~cm}$, respectively, $10.6-18.5 \mathrm{mg} / \mathrm{kg}$.

Among the variants studied, the largest content of nitrate nitrogen in the spring (sowing phase) was in variants with green manure. In fallow arable land (control), despite the application of 20 tons/ha of manure, content of the nitrate nitrogen was $1.5-1.7$ times lower. This can be explained by the fact that the rate of mineralization of manure in the first year is twice lower than that of green mass of plants. This pattern continued in the summer (flowering phase).

The use of lupine as a green manure crop contributed to the greatest accumulation of nitrate nitrogen in the soil. The amount of nitrogen before sowing in this variant was $42.8 \mathrm{mg} / \mathrm{kg}$ in the $0-20 \mathrm{~cm}$ layer of soil and $27.4 \mathrm{mg} / \mathrm{kg}$ in the $20-40 \mathrm{~cm}$ layer. The same accumulation of nitrogen was provided by joint sowing of lupine and peas: $41.2 \mathrm{mg} / \mathrm{kg}$ in the $0-20 \mathrm{~cm}$ layer and $25.1 \mathrm{mg} / \mathrm{kg}$ in the $20-40 \mathrm{~cm}$ layer. The difference between these options was within the experimental error. A slightly lower nitrate nitrogen content was after plowing peas and soy into the soil, both before planting and during flowering. Decrease of nitrogen content in these cases can be explained by a decrease in mass of plants plowed into the soil.

The methods of soil treatment had little or no effect on the accumulation of nitrate nitrogen in the upper layer $(0-20 \mathrm{~cm})$. In all variants, the differences in this indicator were within the experimental error.

In the soil layer $20-40 \mathrm{~cm}$ in the variants with plowing, the nitrate nitrogen content was significantly higher compared to similar variants when blade loosening the soil to a depth of $10-12 \mathrm{~cm}$. So, when plowing in lupine to the depth of $25-28 \mathrm{~cm}$, the amount of nitrogen in the $0-20 \mathrm{~cm}$ layer in spring was $27.4 \mathrm{mg} / \mathrm{kg}$, and when blade loosening to a depth of 10 $12 \mathrm{~cm}$, its amount was $17.3 \mathrm{mg} / \mathrm{kg}$ or 1.6 times less.

When blade loosening, the green manure is concentrated at a depth of up to $15 \mathrm{~cm}$, where the mineralization of rotted plants happens. Formation plowing to the depth of $25-28 \mathrm{~cm}$ contributed to a deeper layering of green manure, which further affected the increase in nitrate nitrogen in this horizon. As we know, maize has a well-developed root system, which penetrates to great depths. Therefore, the presence of a large amount of nitrate nitrogen in the root zone will ensure better plant growth and higher productivity.

The nitrate nitrogen content varied during the growing season. Its largest amount was in the spring period, both in variants with plowing to a depth of 25$28 \mathrm{~cm}$, and in variants with blade loosening to a depth of $10-12 \mathrm{~cm}$. So, when sowing, the nitrate nitrogen content in the soil layer $0-20 \mathrm{~cm}$ on average for 4 years amounted to $21.3-42.8 \mathrm{mg} / \mathrm{kg}$, depending on the variant. During the flowering period, the nitrate nitrogen content in similar variants decreased to $17.4-29.1 \mathrm{mg} / \mathrm{kg}$. As we know, in the initial growth period, maize plants consume a rather small amount of nutrients, including nitrogen. Maximum nitrogen consumption happens during the 
flowering phase, which is what explains a decrease in nitrogen content of the soil.

The content of available phosphorus in the soil also largely depended on predecessors and ways of soil preparation (table 2).

Table 2. Available phosphorus content of the soil for growing maize, depending on the predecessor and the method of soil preparation, $\mathrm{mg} / \mathrm{kg}$ (2016-2019).

\begin{tabular}{|c|c|c|c|c|}
\hline \multirow{2}{*}{$\begin{array}{c}\text { Predecessors } \\
\text { (Factor A) }\end{array}$} & \multirow{2}{*}{$\begin{array}{c}\text { Soil } \\
\text { treatment } \\
\text { (factor B) }\end{array}$} & \multirow{2}{*}{$\begin{array}{c}\text { Layer } \\
\text { of soil, } \\
\text { cm }\end{array}$} & \multicolumn{2}{|c|}{ Sampling dates } \\
\hline & & & Sowing & Flowering \\
\hline \multirow{2}{*}{$\begin{array}{l}\text { Fallow arable } \\
\text { land (control) }\end{array}$} & \multirow{10}{*}{$\begin{array}{l}\text { Plowing } \\
\text { to the } \\
\text { depth of } \\
25-28 \mathrm{~cm}\end{array}$} & $0-20$ & 122 & 104 \\
\hline & & $20-40$ & 109 & 97 \\
\hline \multirow{2}{*}{$\begin{array}{l}\text { Lupine as green } \\
\text { manure }\end{array}$} & & $0-20$ & 179 & 137 \\
\hline & & $20-40$ & 126 & 108 \\
\hline \multirow{2}{*}{$\begin{array}{l}\text { Peas as green } \\
\text { manure }\end{array}$} & & $0-20$ & 160 & 123 \\
\hline & & $20-40$ & 119 & 107 \\
\hline \multirow{2}{*}{$\begin{array}{l}\text { Lupine and peas } \\
\text { as green manure }\end{array}$} & & $0-20$ & 171 & 124 \\
\hline & & $20-40$ & 125 & 113 \\
\hline \multirow{2}{*}{$\begin{array}{l}\text { Soy as green } \\
\text { manure }\end{array}$} & & $0-20$ & 151 & 119 \\
\hline & & $20-40$ & 122 & 110 \\
\hline \multirow{2}{*}{$\begin{array}{l}\text { Fallow arable } \\
\text { land (control) }\end{array}$} & \multirow{10}{*}{$\begin{array}{l}\text { Blade } \\
\text { loosening } \\
\text { to the } \\
\text { depth of } \\
10-12 \mathrm{~cm}\end{array}$} & $0-20$ & 120 & 101 \\
\hline & & $20-40$ & 106 & 97 \\
\hline \multirow{2}{*}{$\begin{array}{l}\text { Lupine as green } \\
\text { manure }\end{array}$} & & $0-20$ & 181 & 141 \\
\hline & & $20-40$ & 111 & 99 \\
\hline \multirow{2}{*}{$\begin{array}{l}\text { Peas as green } \\
\text { manure }\end{array}$} & & $0-20$ & 157 & 121 \\
\hline & & $20-40$ & 108 & 96 \\
\hline \multirow{2}{*}{$\begin{array}{l}\text { Lupine and peas } \\
\text { as green manure }\end{array}$} & & $0-20$ & 169 & 123 \\
\hline & & $20-40$ & 113 & 97 \\
\hline \multirow{2}{*}{$\begin{array}{l}\text { Soy as green } \\
\text { manure }\end{array}$} & & $0-20$ & 147 & 117 \\
\hline & & $20-40$ & 107 & 94 \\
\hline
\end{tabular}

The lowest amount of available phosphorus, regardless of the method of soil preparation, for fallow arable land in the 0-20 cm layer, was: $122 \mathrm{mg} / \mathrm{kg}$ during the planting of maize and $104 \mathrm{mg} / \mathrm{kg}$ during flowering. In variants with the cultivation of legumes as green manure, the content of available phosphorus in this horizon was significantly higher $-147-171 \mathrm{mg} / \mathrm{kg}$. At the same time, the largest amount of available phosphorus on average for 4 years was observed in the variant with the single-component sowing of lupine and in the variant with joint sowing of lupine and peas. In these variants the mobile phosphorus contents was 179$181 \mathrm{mg} / \mathrm{kg}$ and $169-171 \mathrm{mg} / \mathrm{kg}$ respectively. There was a bit less phosphorus with single-component sowing of peas and soy: $157-160 \mathrm{mg} / \mathrm{kg}$ and $147-151 \mathrm{mg} / \mathrm{kg}$ respectively. The content of active phosphorus in the soil layer $0-20 \mathrm{~cm}$ depended mainly on the amount of accumulated mass of green manure plants and the content of phosphorus in it.

In the soil layer $20-40 \mathrm{~cm}$, the content of available phosphorus was influenced by the way the soil was processed. Plowing to a depth of $25-28 \mathrm{~cm}$ contributed to the greater accumulation of this element relatively to surface treatment. In the first case, the phosphorus content was 1.2 to 1.4 times higher.

During the flowering phase, the content of available phosphorus in all variants was significantly lower than during maize planting, which is also explained by the maximum consumption of it in summer.
The content of exchangeable potassium, as well as nitrogen and phosphorus is mostly dependent on the predecessor, timing of vegetation and depth of sampling (table 3).

The highest content of exchangeable potassium was provided by lupine green manure - 209-213 mg/kg in the $0-20 \mathrm{~cm}$ layer of soil and lupine planted together with peas - 196-207 mg/kg. The minimum amount of exchangeable potassium was in fallow arable land, 143$146 \mathrm{mg} / \mathrm{kg}$, depending on the way the soil was processed.

Plowing the soil to a depth of $25-28 \mathrm{~cm}$, similarly to other elements, contributed to a greater accumulation of exchangeable potassium in the soil layer $20-40 \mathrm{~cm}$, relative to surface treatment to a depth of 10-12 cm.

Table 3. Exchange potassium content of the soil for growing maize, depending on the predecessor and the method of soil preparation, $\mathrm{mg} / \mathrm{kg}(2016-2019)$.

\begin{tabular}{|c|c|c|c|c|}
\hline \multirow{2}{*}{$\begin{array}{c}\text { Predecessors } \\
\text { (Factor A) }\end{array}$} & \multirow{2}{*}{$\begin{array}{c}\text { Soil } \\
\text { treatment } \\
\text { (factor B) }\end{array}$} & \multirow{2}{*}{$\begin{array}{c}\text { Layer } \\
\text { of soil, } \\
\text { cm }\end{array}$} & \multicolumn{2}{|c|}{ Sampling dates } \\
\hline & & & Sowing & Flowering \\
\hline \multirow{2}{*}{$\begin{array}{l}\text { Fallow arable } \\
\text { land (control) }\end{array}$} & \multirow{10}{*}{$\begin{array}{l}\text { Plowing } \\
\text { to the } \\
\text { depth of } \\
25-28 \mathrm{~cm}\end{array}$} & $0-20$ & 143 & 121 \\
\hline & & $20-40$ & 121 & 112 \\
\hline \multirow{2}{*}{$\begin{array}{l}\text { Lupine as green } \\
\text { manure }\end{array}$} & & $0-20$ & 213 & 148 \\
\hline & & $20-40$ & 179 & 132 \\
\hline \multirow{2}{*}{$\begin{array}{l}\text { Peas as green } \\
\text { manure }\end{array}$} & & $0-20$ & 192 & 127 \\
\hline & & $20-40$ & 147 & 122 \\
\hline \multirow{2}{*}{$\begin{array}{l}\text { Lupine and peas } \\
\text { as green manure }\end{array}$} & & $0-20$ & 207 & 136 \\
\hline & & $20-40$ & 168 & 121 \\
\hline \multirow{2}{*}{$\begin{array}{l}\text { Soy as green } \\
\text { manure }\end{array}$} & & $0-20$ & 187 & 127 \\
\hline & & $20-40$ & 163 & 119 \\
\hline \multirow{2}{*}{$\begin{array}{l}\text { Fallow arable } \\
\text { land (control) }\end{array}$} & \multirow{10}{*}{$\begin{array}{l}\text { Blade } \\
\text { loosening } \\
\text { to the } \\
\text { depth of } \\
10-12 \mathrm{~cm}\end{array}$} & $0-20$ & 146 & 128 \\
\hline & & $20-40$ & 114 & 105 \\
\hline \multirow{2}{*}{$\begin{array}{l}\text { Lupine as green } \\
\text { manure }\end{array}$} & & $0-20$ & 209 & 137 \\
\hline & & $20-40$ & 151 & 121 \\
\hline \multirow{2}{*}{$\begin{array}{l}\text { Peas as green } \\
\text { manure }\end{array}$} & & $0-20$ & 188 & 134 \\
\hline & & $20-40$ & 133 & 118 \\
\hline \multirow{2}{*}{$\begin{array}{l}\text { Lupine and peas } \\
\text { as green manure }\end{array}$} & & $0-20$ & 196 & 132 \\
\hline & & $20-40$ & 141 & 113 \\
\hline \multirow{2}{*}{$\begin{array}{l}\text { Soy as green } \\
\text { manure }\end{array}$} & & $0-20$ & 179 & 122 \\
\hline & & $20-40$ & 128 & 111 \\
\hline
\end{tabular}

Higher potassium consumption by maize plants happened in the flowering phase, as in other cases, which explains the lower content of it relative to the spring period.

\section{Conclusion}

1. Green manure crops provided greater accumulation of nutrients in the soil compared to fallow arable land, where their number was $1.4-1.7$ times less. The highest amount of nutrients is observed in the soil after applying lupine green manure.

2. In the upper horizons of the soil $(0-20 \mathrm{~cm})$ the methods of soil treatment had no effect on the content of nitrate nitrogen, available phosphorus and exchangeable potassium.

3. Plowing to a depth of $25-28 \mathrm{~cm}$ had a positive effect on the content of nutrients in the $20-40 \mathrm{~cm}$ soil layer. In 
surface-treated variants, their content was $10-16 \%$ lower.

4. During the flowering phase, the contents of movable forms of nitrogen, phosphorus and potassium were reduced by $20-25 \%$ compared to the spring period, which is due to their maximum consumption by maize plants.

\section{References}

[1] Y.I. Kudashov, Influence of various green manure crops on soil fertility and productivity of the link of crop rotation in the South-Eastern part of the Southeastern part of Central Black Earth zone, a Ph.D. thesis (Kamennaya Step, 21, 1996).

[2] S.D. Lyukov, A.F. Glukhovchenko, A.I. Titovskaya, Agrochemical survey of agrophysical properties of soil and grain productivity of maize at various soil processing and fertilizer doses, Innovation in the APC: Problems and Prospects, 3, 23, 130-141 (2019).

[3] V.G. Mineev, V.G. Sychev, G.P. Gamzikov, A.K. Sheujen, E.V. Agafonov, et al., Agrochemistry (Publishing House of VNIIA named after D.N. Pryanishnikov, Moscow, 854, 2017).

[4] Z. Ni, Q. Han, Y.Q. He, S. Huang, Application of genome-editing technology in crop improvement, Cereal chemistry. American Association of Cereal Chemists, Inc., 95, 1, 35-48 (2018).

[5] M. Shi, Y. Liu, Q. Gao, Corn, potato, and wrinkled pea starches with heat-moisture treatment: structure and digestibility, Cereal chemistry. American Association of Cereal Chemists, Inc., 95, 5 (2018).

[6] V.A. Zaginalov, V.A. Shevchenko, Growth, development and productivity of maize with various technologies of cultivation in the nonblack-earth zone of Russia, Fertility 2, 14-16 (2011).

[7] A.K. Indoria, Rao Ch. Srinivasa, K.L. Sharma, Reddy K. Sammi, Conservation agriculture - a panacea to improve soil physical health, Current science, 112, 1 (2017).

[8] N. Gougoulias, G. Papapolymerou, V. Karayannis, X. Spiliotis, N. Chouliaras, Effect of manure enriched with Chlorella vulgaris algae on the chemical properties of the soil, Soil and Water Res., 13, 51-59 (2018). DOI: 10.17221/260/2016-SWR.

[9] M. Kulhánek, J. Černý, J. Balík, O. Sedlář, F. Vašák, Change in the content of bioavailable phosphorus in the soil in years of field experience on fertilizer, Soil and Water Res., 14, 240-245 (2019). DOI: 10.17221/175/2018-SWR.

[10] V.N. Bagrintseva, G.N. Sukhoyarskaya, Effect of fertilizers on maize yields, Corn and sorghum, 4 , 12-14 (2010).

[11] B.N. Ghosh, P. Dogra, N.K. Sharma, R. Bhattacharyya, P.K. Mishra, Conservation impact for soil conservation in the maize-wheat cropping system in the Indian, Sub-Himalayas, Int. Soil Water Conserv. Res. (2015). DOI: 10.1016/j.iswcr.2015.05.001.

[12] J. Janků, P. Sekáč, J. Barákova, J. Kozák, Land use analysis in terms of the protection of agricultural land in the Czech Republic, Soil and Water Res., 11, 20-28 (2016). DOI: 10.17221/163/2015-SWR.

[13] I.V. Mamatov, Efficiency of fertilizers for corn for producing silage in the link of grain-ploughed crop rotation at various methods of their plowing in the typical black earth (Moscow, 26, 1994).

[14] C. Sławiński, J. Cymerman, B. WitkowskaWalczak, K. Lamorski, Impact of diverse tillage on soil moisture dynamics, Int. J. Agrophys., 26, 301-309 (2015).

[15] A.D. Kozhukhov, A.G. Gurin, S.A. Plygun, Features of physiological and phytosanitary activitiesof maize plants using unconventional organicfertilizers, Russian Journal of Agricultural and Socio-Economic Sciences, 7, 23-31 (2012).

[16] A.M. Khlopyanikov, Maize cultivation in adaptive farming technologies of the Southwest of the Central Black Earth, a D.Sc thesis (Bryansk, 385, 2010).

[17] B. Soumitra, D. Kundu, Comparative overview of ethanol production from cereal grains and potato by enzymatic treatment, International Journal of Research in Engineering and Advanced Technology, 1, 236-238 (2013).

[18] L.J. Munkholm, R.J. Heck, B. Deen, Influence of long-term crop rotation and soil processing on soil structure and crop yields, Soil and soil processing research, 127, 85-91 (2013).

[19] T.J. Anderson, B.P. Lamsal, Zein extraction from corn, corn products and coproducts and modifications for various applications: a review, Cereal Chemistry, 88, 171-173 (2011).

[20] P. Kaur, M. Rausch, E. Tumbleson, V. Singh, Enzymatic process for corn dry-grind high-solids fermentation, Cereal Chem., 4, 429-433 (2011).

[21] V. Kiniulis, D. Steponavičius, A. Kemzuraite, A. Andriušis, D. Juknevičius, Dynamic indicators of a corn ear threshing process influenced by the threshing-separation unit load, Mechanika, 24, 4, 412-421 (2018).

[22] B.A. Yagodin, J.P. Shchukov, V.I. Kobzararenko, Agrochemistry (Kolos, Moscow, 584, 2002).

[23] F. Akbas, H. Gunal, N. Acir, Spatial variability of soil potassium and its association with land use and maternal material, Soil and Water Res., 12, 202-211 (2017). DOI: 10.17221/32/2016SWR.

[24] V. Brant, M. Krulik, J. Pivets, P. Zabransky, J. Hackl, J. Holec, J. Kviz, L. Prochazka, A surge of erosion in maize crops in conservation management combined with shallow strip tillage before planting, Soil and Water Res., 12, 106-116 (2017). DOI: 10.17221/147/2015-SWR. 